\title{
A PRELIMINARY OVERVIEW OF RAPTOR MONITORING IN Slovenia - AN OVERVIEW OF METHODOLOGIES, CURRENT MONITORING STATUS AND FUTURE PERSPECTIVES
}

\section{Predhodni pregled monitoringa ptic roparic v Sloveniji - pregled metodologij, trenutnega stanja monitoringa in perspektive}

\author{
Al VReZeC \\ National Institute of Biology, Večna pot 111, SI-1000 Ljubljana, Slovenia, e-mail: al.vrezec@nib.si \\ Slovenian Museum of Natural History, Prešernova 20, SI-1000 Ljubljana, Slovenia
}

\begin{abstract}
Among 48 raptor species (birds of prey, owls, shrikes) recorded recently in Slovenia, some long-term monitoring activities are being conducted for more than half of them, mainly for conservation and research purposes. However, national coverage is achieved only in $15 \%$ of the species, whereas other monitoring programmes are more or less local. Two monitoring approaches are considered, the species specific approach and assemblage approach. Current ongoing monitoring programmes for raptors in Slovenia lack monitoring of breeding success, which is now confined to only a few owl species. Use of nestboxes should therefore be considered more broadly in the future for some species at least.
\end{abstract}

Key words: Slovenia, raptor monitoring, monitoring methodology, birds of prey, owls, shrikes

Ključne besede: Slovenija, monitoring ptic roparic, metodologija monitoringa, ujede, sove, srakoperji

\section{Introduction}

Despite a relatively long ornithological research tradition (SCOPOLI 1769) and certain conservation efforts for many raptor species in Slovenia (Beuk I920), the actual bird monitoring programmes and studies were embarked upon fairly recently, specifically in the 1980s. The aims of these monitoring programmes were quite different taking into account specific scientific (ToMe 2009) or conservation based issues (PolaK et al. 2004). They were designed either as broad international actions (Božič 2005) or as a way of bird popularization by monitoring of charismatic bird species (Denac, D. 20Io). Therefore long-term data on bird or specifically raptor populations in Slovenia are of quite different quality and quantity based on species specific or assemblage-oriented surveys such as Farmland Bird Index counts (KMECL \& FIGELJ 20I2). In terms of raptors, only few long-term monitoring results from Slovenia have been published (e.g. Denac 2003, Rubinić 2009, Tome 2009,
VREZEC et al. 2009), leaving most of the collected data unanalysed and unpublished.

The main aim of this study was therefore to inventory data collections in Slovenia appropriate for raptor monitoring purposes. I have taken into account the published and unpublished long-term data on population size (breeding and non-breeding) and breeding success, including survey methods overview, and identified strong and weak points of current monitoring programmes with future perspectives and needs. In the present preliminary overview of raptor monitoring in Slovenia, I have followed broader ecological definition of raptors including birds of prey, owls and shrikes.

\section{Methods}

For the purpose of this overview, an updated list of raptors recorded in Slovenia in the past 50 years was prepared. For each species the inventory of continuous or consecutive surveillances and especially long-term 
A. VReZeC: A preliminary overview of raptor monitoring in Slovenia - an overview of methodologies, current monitoring status and future perspectives

Table 1: Overview of raptor monitoring in Slovenia (the number of species listed)

Tabela 1: Pregled monitoringa ptic roparic v Sloveniji (z navedenim številom vrst)

\begin{tabular}{|c|c|c|c|c|}
\hline & Falconiformes & Strigiformes & Laniidae & Total / Skupaj \\
\hline No. of species & 34 & I I & 4 & 49 \\
\hline Breeders & I5 & 9 & 3 & 27 \\
\hline Vagrants & IO & I & o & II \\
\hline Monitoring of breeding population & 7 & 6 & 2 & 15 \\
\hline Monitoring of breeding success & 2 & 5 & I & 8 \\
\hline Raptor migration monitoring & I3 & o & I & I 4 \\
\hline Monitoring of wintering population & I & $\mathrm{o}$ & I & 2 \\
\hline
\end{tabular}

monitoring programmes was reviewed, taking into account the published data, unpublished reports, existing data bases or survey protocols.

\section{Results and discussion}

In the past 50 years, 49 raptor species have been recorded in Slovenia. Breeding has been confirmed for 27 of them (five species became recently extinct or breed irregularly or in very low numbers), at least 22 species are regular migrants, and at least five species form regular wintering populations (Sovinc I994, Geister i 995, Bordjan \& Božič 2009, HanžEl \& ŠERE 2OI I) (Table 1). From further analysis, 11 vagrant species have been excluded. For $71 \%$ of non-vagrant species, some long-term monitoring activities exist.

\subsection{Monitoring schemes, data users}

Monitoring of breeding populations was carried out for $58 \%$ of the breeders, but the actual breeding success was ascertained only for $27 \%$ of them. In raptor migration monitoring, 37\% of the species were considered, and only $5 \%$ in wintering population monitoring (Table 1). However, the spatial coverage and time series differ greatly among species.

The largest data set was obtained from regular ringing of migrating passerines (coordinated by the Slovenian Museum of Natural History) for the Redbacked Shrike Lanius collurio, which started as early as in 1927, but systematically continued at a permanent bird ringing station in 1987 (BOžIČ 2009, Š́ERE 2009). Other monitoring programmes are much shorter and confined mainly to the last 20 years. They were mostly conducted by DOPPS - BirdLife Slovenia, Sečovlje Salina Nature Park and the National Institute of Biology for research, conservation and management purposes.

Data users and monitoring programmes' supporters are mainly governmental institutions from the field of nature conservation (Ministry of Agriculture and Environment, Institute of the Republic of Slovenia for Nature Conservation) and scientific research (Slovenian Research Agency, Ministry of Culture). Quite some monitoring efforts rely also on purely voluntary work.

National coverage was achieved only in seven species (18\%), mostly as breeding population monitoring. For 20 species $(53 \%)$, the monitoring programmes were local (one or two sites). The latter were mainly migration monitoring programmes at specific sites, including monitoring of several migrating raptor species.

\subsection{Monitoring methodology, key species and key monitoring issues}

Two monitoring approaches are considered in the scope of long-term data collection for raptors, species specific approach and assemblage approach.

In the latter, raptors are target species of raptor migration monitoring, which is conducted at migration bottlenecks or other important migration sites, e.g. open wetlands, in Slovenia. Raptor migration monitoring has been conducted since 2005 on eight sites in Slovenia, but only on one more or less regularly within the scope of Natura 2000 network monitoring programme (DENAC et al. 20IO). This monitoring was conducted in spring and autumn and every raptor species was recorded, with Honey Buzzard Pernis apivorus, Griffon Vulture Gyps fulvus and Kestrel Falco tinnunculus as the most abundant raptors, the last two species as residents and not true migrants (DENAC, K. 20Io).

Raptor migration is followed also within regular bird ringing programme coordinated by the Slovenian Museum of Natural History, but these data have not yet been fully evaluated for the monitoring purposes.

Migration of raptors, mostly birds of prey, is 
followed seasonally and annually also in the scope of waterbird counts at larger wetlands in Slovenia. This has been regularly conducted since 2002 (since 1983 at only one site) on at least five sites, in which migrating as well as breeding and wintering raptor populations are considered, with Marsh Harrier Circus aeruginosus, Buzzard Buteo buteo, Red-footed Falcon F. vespertinus, Kestrel and Osprey Pandion haliaetus as the most abundant species (BORdJAN \& BožIČ 2009, ŠKORNIK 2009, BORDJAN 20I2). For the White-tailed Eagle Haliaeetus albicilla, the usefulness of large scale and non-targeted data from International Waterbird Census (IWC) counts has been shown. In Slovenia, the IWC has been continuously conducted on almost all water bodies since 1997 (ŠTUMBERGER I997). Despite winter counts, this survey appeared to be very useful for estimating breeding population trends of the White-tailed Eagle (VREZEC et al. 2009). An increase in winter population (estimated with TRIM software) corresponded very well to the increase of new nests found.

Breeding population of some species is followed in consecutive periods, although not annually, for example for the Red-backed Shrike, where local population is surveyed approximately every five years (DENAC 2003). Since 2007, breeding populations of some common raptors, e.g. Kestrel and Red-backed Shrike, have been followed by annual bird surveys conducted on 102 plots over the country as part of the Farmland Bird Index programme, conducted by DOPPS - BirdLife Slovenia (KMECl \& FigelJ 20 I2).

Collection of biological material (carcasses, eggs, feathers etc.) that might be an important source for with raptor monitoring, i.e. monitoring of contaminants in raptor tissues, is conducted by the Slovenian Museum of Natural History, but with no specific collection programme for raptors so far.

The species specific monitoring programmes are focused mainly on breeders (Table 2), with the exception of the Great Grey Shrike L. excubitor for which regular surveys of its winter numbers have been conducted since 2000, currently on two larger open areas in Slovenia at least, using the area count method (Bомвек 200I). Some endangered raptor species have been included in the national monitoring scheme of qualification species of the Natura 2000 network: Lesser Spotted Eagle Aquila pomarina, Peregrine Falcon F. peregrinus, Scops Owl Otus scops, Eagle Owl Bubo bubo, Ural Owl Strix uralensis and Lesser Grey Shrike L. minor (Rubinić 2009, Denac et al. 2010). However, the species specific monitoring programmes are focused mostly on territorial pair counts or chick presence in the nest at most, but rarely on other breeding and ecological parameters (Table 2). These were part of more detailed but local studies of feeding and breeding ecology in raptors (i.e. Long-eared Owl Asio otus, Tome 2003 \& 2009) or research nestbox programme (i.e. Tawny $S$. aluco and Ural Owl, Vrezec 2007 \& unpubl.).

Many monitoring programmes in Slovenia are part of a broad international cooperation, especially with BirdLife International. Migration monitoring was designed in cooperation with Austrian and Italian researchers (Minelič \& Genero 2005, Probst 2010), whereas species specific monitoring of owls was developed in close cooperation with Finnish, Croatian, Italian, Austrian and some other researchers (e.g. VRezec \& Tutiš 2003). Currently, there is a bilateral project with Bosnia and Herzegovina going on, aimed at joint study of some owl species.

\subsection{Strengths and weaknesses of current monitoring programmes, future perspectives}

Monitoring programmes should be cost-effective (McDonald-Madden et al. 2010) to ensure longterm surveillance according to limited financial and human resources on one hand and its information efficiency on the other, which includes large scale and complex survey approach. Since raptors are charismatic and usually well known species, it is important to search for possibilities at least for their population monitoring in current ongoing monitoring programmes, e.g. population monitoring of the White-tailed Eagle in Slovenia (VRezec et al. 2009). In Slovenia, however, nearly a half of raptor species are currently not covered by any monitoring programme or only migrating population is monitored, while their breeding populations have not been taken into consideration.

In Slovenia, monitoring of raptors' breeding success is currently confined to just few owl species (Table 2). The use of nestboxes is still underrepresented in raptor monitoring and research (LAMBRECHTs et al. 20I2) and should be more broadly used. In general, the conservation needs for nestboxes in order to supplement nest sites for hole nesting raptors are low due to still well preserved forest stands in Slovenia, which provide enough natural possibilities for breeding. Currently, nestboxes are used for Kestrel, Barn Owl Tyto alba, Scops Owl, Tawny Owl, Ural Owl, Tengmalm's owl Aegolius funereus and Little Owl Athene noctua, although mostly at the local level with low quantity and different success. However, the perspective of nestbox application in monitoring programmes is to recruit volunteers to maintain 
A. VRezec: A preliminary overview of raptor monitoring in Slovenia - an overview of methodologies, current monitoring status and future perspectives

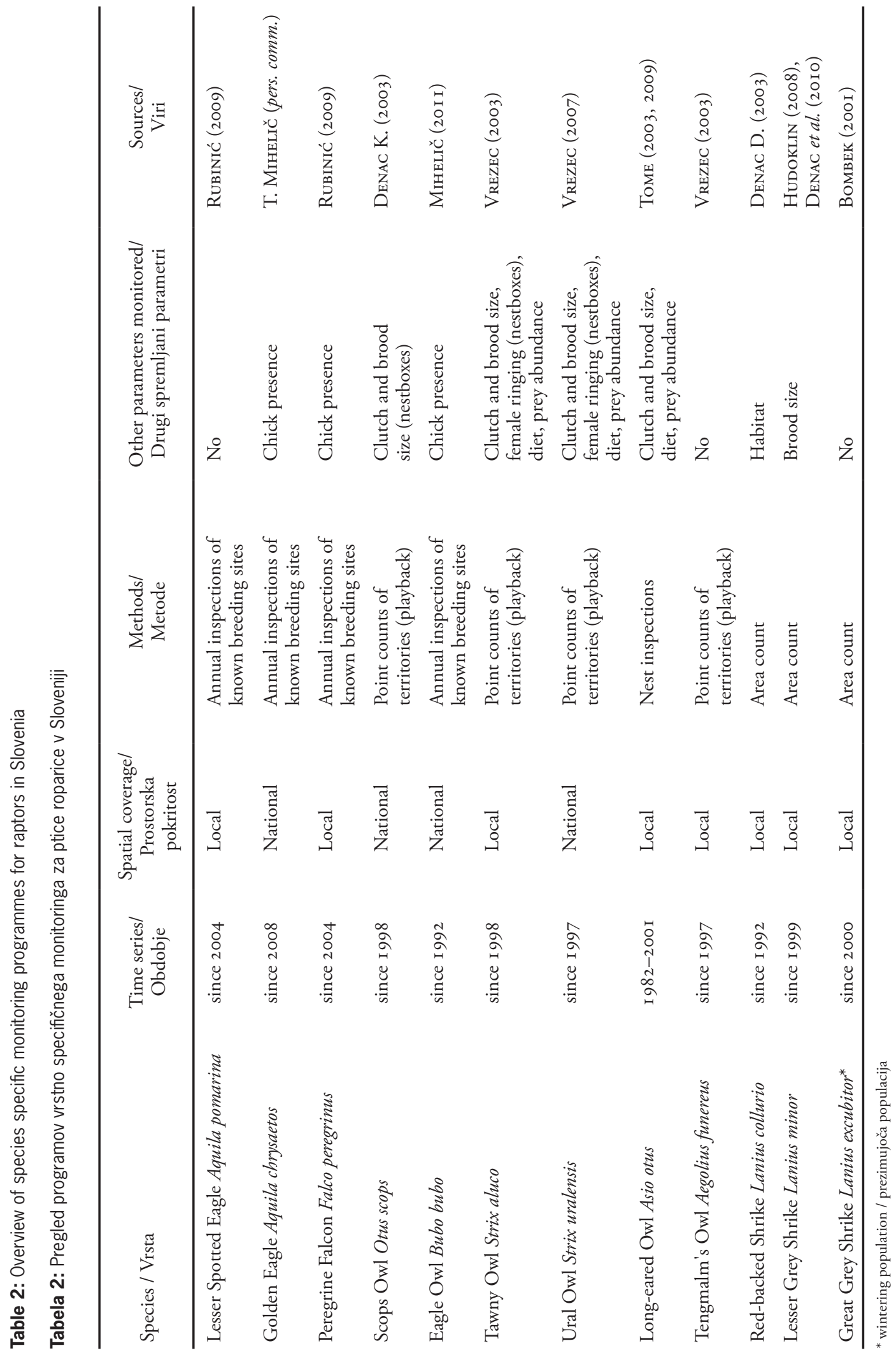


different kinds of nestboxes for raptors. Based on Finnish raptor monitoring programme (SAUROLA 2008), this provides good population as well as breeding success monitoring.

In order to explain monitoring results, some key environmental parameters should be included in the monitoring programmes, which are considered in Slovenia only marginally for research needs (e.g. Tome 2009). Especially, there is a need for monitoring of threats, which have been studied in Slovenia only preliminary, e.g. roadkill (RUBINIČ \& VREZEC 200I) and electrocution (Rubinić 2009), but not followed by a long-term scheme and connected to population monitoring programmes.

The future perspectives of monitoring for raptors in Slovenia, largely stimulated by EURAPMON, are: (1) to collect current scattered data and to produce reliable national trends where possible, (2) to develop efficient field methods (survey, breeding success), (3) to start with nestboxes programme at the national level (volunteer-based), (4) to include ringing activity and advanced telemetry studies into raptor monitoring, (5) to include mortality monitoring or monitoring of threats, and (6) to start with systematic biological material collection of raptors for the purposes of monitoring with raptors. These issues should be largely enhanced by international cooperation at the point of general monitoring scheme establishment.

Acknowledgements: To accomplish this overview, several colleagues offered me great help in obtaining additional information on unpublished but ongoing monitoring programmes for raptors in Slovenia: Dominik Bombek, Dejan Bordjan, Katarina Denac, Dare Fekonja, Dr Primož Kmecelj, Dr Urša Koce, Tomaž Mihelič and Dr Davorin Tome.

\section{Povzetek}

Dolgoročni monitoring trenutno poteka za dobro polovico od 48 ptic roparic (ujed, sov, srakoperjev), zabeleženih v zadnjem obdobju v Sloveniji, predvsem za potrebe varstva in raziskovanja teh ptic. Vendar pa je na nacionalni ravni pokritih le $15 \%$ vrst, medtem ko drugi programi monitoringa potekajo bolj ali manj na lokalno. $V$ rabi sta dva pristopa monitoringa, in sicer vrstno specifični pristop in pristop na ravni združb. Sedanji programi monitoringa za ptice roparice $\mathrm{v}$ Sloveniji pa ne zajemajo monitoringa njihovega gnezditvenega uspeha, ki je trenutno omejen le na sove. V prihodnosti bi za nadaljnji razvoj monitoronga ptic roparic v Sloveniji morali razmisliti predvsem o: (1) zbiranju obstoječih a razpršenih podatkov, $s$ katerimi bi lahko izračunali zanesljive populacijske trende vsaj za nekatere vrste, (2) razvoju učinkovitih terenskih metod (popisi, ugotavljanje gnezditvenega uspeha), (3) začetku programa $\mathrm{z}$ uporabo gnezdilnic na nacionalnem nivoju (s širšim vključevanjem prostovoljcev), (4) vključitvi obročkovalske aktivnosti in uporabe naprednih telemetrijskih tehnik $\mathrm{v}$ monitoring ptic roparic, (5) vključitvi monitoringa smrtnosti in dejavnikov ogrožanja $\mathrm{v}$ sheme monitoringa in (6) začetku sistematičnega zbiranja biološkega materiala ptic roparic za namene monitoringa onesnažil in strupov. Ti cilji morajo biti tesno povezani z mednarodnim sodelovanjem za postavitev nacionalne sheme monitoringa za ptice roparice v Sloveniji.

\section{References}

Beuk, S. (I 920): Spomenica. - Glasnik Muzejskega društva za Slovenijo 1 (1-4): 69-75. (in Slovene)

Вомвек, D. (200I): [Survey of the Great Grey Shrike Lanius excubitor at Dravsko and Ptujsko polje in December 2000.] - Acrocephalus 22 (104/105): 41-43. (in Slovene, English summary).

BORDJAN, D. (2012): [Waterbirds and raptors of Cerknica polje (southern Slovenia) in 2007 and 2008, with an overview of interesting observations till the end of 2010.] - Acrocephalus 33 (152/153): 25-104. (in Slovene, English summary)

BORDJAN, D. \& BožIČ, L. (2009): [Waterbirds and raptors occurring in the area of Medvedce reservoir (Dravsko polje, NE Slovenia) during the 2002-2008 period.] Acrocephalus 30 (141/142/143): 55-163. (in Slovene, English summary)

BožIČ, L. (2005): [Results of the International Waterbird Census (IWC) in January 2004 and 2005 in Slovenia.] - Acrocephalus 26 (126): 123-137. (in Slovene, English summary)

Božıč, I.A. (2009): [Results of bird ringing in Slovenia: 1926-1982.] - Scopolia, Suppl. 4: 23-110. (in Slovene, English summary)

Denac, D. (2003): Population decline and land-use changes in hunting habitat of the Red-backed Shrike Lanius collurio at Sturmovci (NE Slovenia). - Acrocephalus 24 (118): 97-102.

Denac, D. (2010): Population dynamics of the White stork Ciconia ciconia in Slovenia between 1999 and 2010. Acrocephalus 31 (145/146): 101-114.

Denac, K. (2003): Population dynamics of Scops Owl Otus scops at Ljubljansko barje (central Slovenia). Acrocephalus 24 (119): 127-133.

Denac, K. (20 Io): Census of migrating raptors at Breginjski Stol (NW Slovenia) - the first confirmed bottleneck site in Slovenia. - Acrocephalus 31 (145/146): 77-92.

Denac, K., Božič, L., Rubinić, B., Denac, D., Mihelič, T., KMecl, P. \& Bordjan, D. (2010): [Population monitoring of selected bird species. Technical report.] DOPPS - BirdLife Slovenia, Ljubljana. (in Slovene) 
A. VReZeC: A preliminary overview of raptor monitoring in Slovenia - an overview of methodologies, current monitoring status and future perspectives

KMECL, P. \& FigelJ, J. (2012): [Monitoring of common bird species for estimation of Slovenian Farmland Bird Index. Report for 2012.] - DOPPS, Ljubljana. (in Slovene) (available at http://www.natura2000.gov.si/ index.php?id=211)

Geister, I. (I995): [The Ornithological Atlas of Slovenia.] - DZS, Ljubljana. (in Slovene, English summary)

HanžEL, J. \& Š ERE, D. (2O I I): [The list of birds of Slovenia with an overview of rare species.] - Acrocephalus 32 (150/151): 143-203. (in Slovene, English summary)

Hudoklin, A. (2008): [Ecological demands of the Lesser Grey Shrike Lanius minor in its breeding habitat at Šntjernejsko polje (SE Slovenia).] - Acrocephalus 29: 23-31. (in Slovene, English summary)

Lambrechts, M.M., Wiebe, K.L., Sunde, P., Solonen, T., Sergio, F., Roulin, A., Møller, A.P., Lopez, B.C., Fargallo, J.A., Exo, K.M., Dell'Omo, G., Costantini, D., Charter, M., Butler, M.W., Bortolotti, G.R., Arlettaz, R. \& Korpimäki, E. (20I2): Nest box design for the study of diurnal raptors and owls is still an overlooked point in ecological, evolutionary and conservation studies: a review. - Journal of Ornithology 153 (1): 23-34.

Mcdonald-Madden, E., BaXter, P.W.J., Fuller, R.A., Martin, T.G., Game, E.T., Montambault, J. \& Possingham, H.P. (2010): Monitoring does not always count. - Trends in Ecology and Evolution 25: 547-550.

Minelič, T. (20I I): [Eagle Owl Bubo bubo.] pp. 25-33 In: Denac, K., Mihelič, T., Denac, D., Božıč, L., KMecl, P. \& Bordjan, D. (eds.): Population monitoring of selected bird species. Census of breeders in spring 2011 and summary of surveys in the 2010-2011 period. Final report. - DOPPS - BirdLife Slovenia, Ljubljana. (in Slovene)

Minelič, T. \& Genero, F. (2005): Occurrence of Griffon Vulture Gyps fulvus in Slovenia in the period from 1980 to 2005. - Acrocephalus 26 (125): 73-79.

PolaK, S., Kebe, L. \& Koren, B. (2004): [Thirteen years of the Corn Crake Crex crex census at Lake Cerknica (Slovenia).] - Acrocephalus 25 (121): 61-72. (in Slovene, English summary)

Probst, R. (2010): Important sites for migrating raptors in the Eastern Alps. - Acrocephalus 31 (145/146): 73-75.

Rubinić, B. (ed.) (2009): [Birds in Slovenia in the year 2008.] - DOPPS - BirdLife Slovenia, Ljubljana. (in Slovene)

Rubinič, B. \& VRezec, A. (200I): [A contribution to the knowledge of bird mortality on Slovene roads.] Acrocephalus 22 (109): 219-223. (in Slovene, English summary)

Saurola, P. (2008): Monitoring Birds of Prey in Finland: A Summary of Methods, Trends, and Statistical Power. Ambio 37 (6): 413-419.

Scopoli, I.A. (I769): [Annus I. historico-naturalis. Descriptiones Avium.] - Sumtib. Christ. Gottlob Hilscheri, Lipsiae. (in Latin)

Sovinc, A. (1994): [The Atlas of Wintering Birds of Slovenia.] - Tehniška založba Slovenije, Ljubljana. (in Slovene)

ŠERE, D. (2009): [A short report on birds ringed in Slovenia, 1983-2008.] - Scopolia, Suppl. 4: 23-110. (in Slovene,
English summary)

ŠKORnIK, I. (2009): [A Faunistic-Ecological Contribution to the Knowledge of Birds in the Sečovlje Salina.] - Soline pridelava soli, Seča. (in Slovene, English summary)

Štumberger, B. (I 997): [Results of the mid-winter waterfowl census in January 1997 in Slovenia.] Acrocephalus 18 (80/81): 29-39. (in Slovene, English summary)

Tомe, D. (2003): Functional response of the Long-eared Owl (Asio otus) to changing prey numbers: a 20 -year study. - Ornis Fennica 80 (2): 63-70.

Tome, D. (2009): Changes in the diet of long-eared owl Asio otus: seasonal patterns of dependence on vole abundance. - Ardeola 56 (1): 49-56.

VREZEC, A. (2003): Breeding density and altitudinal distribution of the Ural, Tawny, and Boreal Owls in North Dinaric Alps (central Slovenia). - Journal of Raptor Research 37 (1): 55-62.

VREZEC, A. (2007): The Ural Owl (Strix uralensis macroura) - Status and overview of studies in Slovenia. pp. 16-31 In: Müller, J., Scherzinger, W. \& Moning, C. (eds.): European Ural Owl workshop. - Nationalparkverwaltung Bayerischer Wald, Grafenau.

Vrezec, A., Bordjan, D., Perušek, M. \& Hudoklin, A. (2009): Population and ecology of the White-tailed Eagle (Haliaeetus albicilla) and its conservation status in Slovenia. - Denisia 27: 103-114.

Vrezec, A. \& Tutiš, V. (2003): Characteristics of North Dinaric Ural Owl (Strix uralensis macroura) population. pp. 75 In: Schwerdtfeger, O. \& Schwerdtfeger, J. (eds.): Ecology and Conservation of European Owls. International Symposium Dornbirn 2003. - Dornbirn.

Arrived / Prispelo: 27. 3. 2013

Accepted / Sprejeto: 1. 7. 2013 